\title{
Review
}

\section{Seminar Lessons: Infectious Diseases Associated with and Causing Disaster}

\author{
Toshio Hattori ${ }^{1, *(\mathbb{D}, \text { Haorile Chagan-Yasutan }}{ }^{2}$, Shin Koga ${ }^{3}$, Yasutake Yanagihara ${ }^{4}$ and Issei Tanaka ${ }^{5, *}$ \\ 1 Research Institute of Health and Welfare, Kibi International University, Takahashi 716-8508, Japan \\ 2 Mongolian Psychosomatic Medicine Department, International Mongolian Medicine Hospital of Inner Mongolia, \\ Hohhot 010065, China; haorile@gjmyemail.gjmyy.cn \\ 3 Public Interest Incorporated Foundation SBS Shizuoka Health Promotion Center, Shizuoka 422-8033, Japan; \\ s-koga@sbs-smc.or.jp \\ 4 Research Center for Zoonosis Control, Hokkaido University, Sapporo 001-0020, Japan; yanagihara@uv.tnc.ne.jp \\ 5 Shizuoka Prefectural Hospital Organization, Shizuoka 420-8527, Japan \\ * Correspondence: hattorit@kiui.ac.jp (T.H.); issei-tanaka@i.shizuoka-pho.jp (I.T.)
}

Citation: Hattori, T.; Chagan-Yasutan, H.; Koga, S.; Yanagihara, Y.; Tanaka, I Seminar Lessons: Infectious Diseases Associated with and Causing Disaster. Reports 2022, 5, 7. https:// doi.org/10.3390/reports5010007

Academic Editor: Ivana Kholová

Received: 8 February 2022

Accepted: 23 February 2022

Published: 28 February 2022

Publisher's Note: MDPI stays neutral with regard to jurisdictional claims in published maps and institutional affiliations.

Copyright: (C) 2022 by the authors. Licensee MDPI, Basel, Switzerland. This article is an open access article distributed under the terms and conditions of the Creative Commons Attribution (CC BY) license (https:// creativecommons.org/licenses/by/ $4.0 /)$.

\begin{abstract}
Disasters such as the magnitude-9 Great East Japan Earthquake occur periodically. We considered this experience while developing measures against a predicted earthquake in the Nankai Trough. This report includes a summary of 10 disastrous infectious diseases for which a countermeasures seminar was held. Thirty-five speakers from twenty-one organizations performed the lectures. Besides infectious diseases, conference topics also included disaster prevention and mitigation methods. In addition, the development of point-of-care tests, biomarkers for diagnosis, and severity assessments for infectious diseases were introduced, along with epidemics of infectious diseases affected by climate. Of the 28 pathogens that became a hot topic, 17 are viruses, and 14 out of these 17 (82\%) are RNA viruses. Of the 10 seminars, the last 2 targeted only COVID-19. It was emphasized that COVID-19 is not just a disaster-related infection but a disaster itself. The first seminar on COVID-19 provided immunological and epidemiological knowledge and commentary on clinical practices. During the second COVID-19 seminar, vaccine development, virological characteristics, treatment of respiratory failure, biomarkers, and human genetic susceptibility for infectious diseases were discussed. Conducting continuous seminars is important for general infectious controls.
\end{abstract}

Keywords: disaster; infectious diseases; leptospirosis; tuberculosis; dengue; POCT; COVID-19

\section{Introduction}

In 2019, 396 natural disasters were recorded in the Emergency Events Database (EMDAT), with 11,755 deaths, 95 million people affected, and USD 103 billion in economic losses worldwide. This burden was not shared equally since Asia suffered the highest impact, accounting for $40 \%$ of disaster events, $45 \%$ of deaths and $74 \%$ of the total affected [1]. Japan has historically suffered from large-scale natural disasters. Hojoki, one of the oldest essays in Japan, describes a great fire (A.D. 1177), a tornado followed by the relocation of the capital (A.D. 1180), a famine (A.D. 1181-2), and an earthquake (A.D. 1185). Recently, Japan endured the Great East Japan Earthquake and Tsunami (GEJET) of 11 March 2011 - a magnitude-9 earthquake that attacked Sendai and neighboring cities, leaving 20,000 people missing. This area was attacked by a tsunami (Jogan) on 13 July 869 , indicating that large-scale tsunamis occur within a 1000-year interval [2]. The Nankai Trough mega-earthquake (NTME) is anticipated as the next major earthquake in Japan, involving the Shizuoka prefecture. It is anticipated to cause approximately 323,000 deaths and approximately USD 1.5 trillion in direct impact, with a production and service decline amounting to approximately USD 0.4 trillion [3]. Sharing our knowledge of the disaster is one way to initiate effective measures against these disasters. For this purpose, we decided to share our knowledge with annual seminars about infectious diseases that may 
occur due to disasters. The participants were from the International Research Institute of Disaster Science (IRIDeS) at Tohoku University in Sendai who suffered from GEJET, and those involved in disaster countermeasures and medical treatment in the Shizuoka prefecture since 2014. It is important to enhance the resilience of national health systems for disaster risk reduction. Some approaches include integrating disaster risk management into primary, secondary, and tertiary healthcare (especially at the local level), developing health workers' understanding of disaster risks, applying and implementing disaster risk reduction approaches to healthcare, promoting and enhancing training in the field of disaster medicine, and training community health groups in disaster risk reduction through health programs in collaboration with other sectors [4]. During disasters, a lack of safe water access and inadequate sanitation facilities allow the transmission of water-borne and food-borne pathogens. Diarrheal diseases such as cholera, typhoid fever, and shigellosis cause epidemics with high mortality rates. Malaria and other vector-borne diseases in risk areas include arboviruses, such as dengue, yellow fever, Japanese encephalitis, Rift Valley fever, and tick-borne illnesses, including Crimean-Congo hemorrhagic fever and typhus. Diseases associated with overcrowding, such as measles in unvaccinated areas and tuberculosis, can occur after natural disasters. During the seminars, we discussed infectious diseases associated with disasters, such as leptospirosis [5], dengue virus infection [6], and tuberculosis [7,8]. We also discussed biomarkers for these diseases that reflect disease severity [9], and a point-of-care test (POCT) to detect pathogens, including loop-mediated thermal amplification (LAMP) in tuberculosis [10], single-tag hybridization chromatographic-printed array (STH-PAS) [11], and a nanopore technology-based sequencer called MinION [12]. We proposed that acquired immune deficiency syndrome (AIDS) co-infected with tuberculosis (TB) (AIDS/TB) constitutes a natural disaster because the deaths caused by AIDS/TB account for $47 \%$ of all deaths in South Africa [13]. Severe acute respiratory syndrome coronavirus 2 (SARS-CoV-2) [14] caused a pandemic in 2019 (COVID-19) with more than 286 million cases and 5,429,617 deaths by the end of 2021 (https: / / coronavirus.jhu.edu/) (accessed on 30 December 2021). The expansion of the pandemic severely damaged society. Therefore, the last two seminars were held exclusively on SARS-CoV-2 infections. In this manuscript, we introduce 10 seminars on measures against disaster-related infectious diseases and propose the role seminars play in combating infectious diseases associated with disasters.

\section{Content of Seminars}

Table 1 shows the speakers, their lecture titles, and the dates of the seminars in chronological order. The first seminar was held at Shizuoka General Hospital (SGH), followed by a second seminar hosted by the Division of Disaster-related Infectious Diseases (DRI) at IRIDeS. The third seminar was held as part of the third world conference on disaster risk reduction (DRR) in Sendai (2015) (https:/ / www.un.org/press/en/highlights/wcdrr) (accessed on 30 December 2021). The following seminars were conducted based on the Sendai framework for disaster risk reduction [4]. The content of the seminars were classified into categories (Figure 1). Recalling the 10 seminars, 35 speakers from 21 organizations performed lectures about infectious diseases, as well as disaster prevention and mitigation methods. Five of these lectures discussed disaster risk reduction (DRR) from many aspects, including human security [2,15], the United Nations world conference [4], disaster prevention, and measures of the Shizuoka prefecture. 
Table 1. Conference speakers and their titles in chronological order.

\begin{tabular}{|c|c|c|c|c|c|}
\hline No. & Date & Speaker & Affiliation & Title & Classification \\
\hline \multirow[t]{3}{*}{1} & 24 February 2014 & Sato $\mathrm{T}$ & JBCL & $\begin{array}{l}\text { Examination of digestive system required } \\
\text { for disaster infectious diseases }\end{array}$ & E. coli \\
\hline & & Koga S & U. Shizuoka & $\begin{array}{l}\text { Disaster infectious diseases, after } \\
\text { earthquakes and tsunamis }\end{array}$ & DRI \\
\hline & & Hattori $\mathrm{T}$ & IRIDeS & $\begin{array}{l}\text { Human security program against disasters } \\
\text { and infectious diseases }\end{array}$ & DRR \\
\hline \multirow[t]{4}{*}{2} & 19 July 2014 & Sato $\mathrm{T}$ & JBCL & $\begin{array}{l}\text { Examination of digestive system required } \\
\text { for disaster infectious diseases }\end{array}$ & E. coli \\
\hline & & C.-Y. H & IRIDeS & $\begin{array}{l}\text { Disaster-related infectious diseases in } \\
\text { the Philippines }\end{array}$ & Tropical \\
\hline & & Ashino $Y$ & Tohoku U. & $\begin{array}{l}\text { Actual condition of HIV infections in the } \\
\text { Tohoku region of Japan }\end{array}$ & HIV \\
\hline & & Egawa S & IRIDeS & $\begin{array}{l}\text { Medical response in the Great East } \\
\text { Japan Earthquake }\end{array}$ & DRHM \\
\hline \multirow[t]{5}{*}{3} & 13 March 2015 & C.-Y. H & IRIDeS & $\begin{array}{l}\text { Collaborative research on disaster-related } \\
\text { infectious diseases with Philippines }\end{array}$ & Tropical \\
\hline & & Sumi A & SMU & Seasonal tuberculosis epidemic & MTB \\
\hline & & Ndhlovu LC & U. Hawaii & $\begin{array}{l}\text { Consideration of the HIV epidemic during } \\
\text { disaster related events }\end{array}$ & HIV \\
\hline & & Hakamata Y & SGH & $\begin{array}{l}\text { Preparation for disaster-related infectious } \\
\text { diseases in Shizuoka Prefecture }\end{array}$ & DRI \\
\hline & & Suzuki Y & Hokkaido U. & Tuberculosis as a disaster-related disorders & MTB \\
\hline \multirow[t]{5}{*}{4} & 4 July 2015 & Fukuoka T & $\mathrm{SSH}$ & $\begin{array}{c}\text { Experience of outbreak of pathogenic } \\
\text { Escherichia coli O157 }\end{array}$ & E. coli \\
\hline & & Kutsuna K & NCGM & Dengue fever & Tropical \\
\hline & & Kaji M & $\mathrm{SCHC}$ & $\begin{array}{c}\text { About infectious disease measures in } \\
\text { Shizuoka city }\end{array}$ & DRI \\
\hline & & Yanagihara $\mathrm{Y}$ & U. Shizuoka & Floods and leptospirosis in the Philippines & Tropical \\
\hline & & Egawa S & IRIDeS & $\begin{array}{l}\text { Reports of the United Nations world } \\
\text { conference on disaster risk reduction }\end{array}$ & DRR \\
\hline \multirow[t]{5}{*}{5} & 19 November 2016 & Nakayama Y & SKH & $\begin{array}{c}\text { "Chain of survival" Kumamoto earthquake, } \\
\text { crisis of life. }\end{array}$ & DRHM \\
\hline & & C.-Y. H & IRIDeS & $\begin{array}{l}\text { Actual conditions of mosquito-borne } \\
\text { infectious diseases and its spreading }\end{array}$ & Tropical \\
\hline & & Sato $\mathrm{T}$ & JBCL & $\begin{array}{l}\text { Countermeasures against norovirus } \\
\text { infection in the event of disaster }\end{array}$ & Norovirus \\
\hline & & Kawase M & TBA & $\begin{array}{l}\text { Development of new diagnostic method } \\
\text { STH-PAS for infectious diseases }\end{array}$ & POCT \\
\hline & & Koga S & U. Shizuoka & $\begin{array}{l}\text { Current status and countermeasures for } \\
\text { important tick-borne infectious diseases }\end{array}$ & Tick \\
\hline \multirow[t]{5}{*}{6} & 12 December 2017 & Suzuki Y & Hokkaido U. & Tuberculosis; never-ending threat & МTB \\
\hline & & Kawamori F & U. Shizuoka & $\begin{array}{l}\text { Tick-born infectious diseases in Shizuoka } \\
\text { prefecture }\end{array}$ & Tick \\
\hline & & Hakamata Y & SGH & $\begin{array}{l}\text { Summary of pet infectious diseases of } \\
\text { concern at evacuation center }\end{array}$ & Pet infection \\
\hline & & Matsui T & NIID & $\begin{array}{l}\text { Risk assessment method for infectious } \\
\text { disease at evacuation center-to facilitate } \\
\text { 'common language' between infection } \\
\text { control specialists and public health sectors }\end{array}$ & DRHM \\
\hline & & Iwata K & Shizuoka U. & $\begin{array}{l}\text { From disaster mitigation to disaster } \\
\text { prevention society }\end{array}$ & DRR \\
\hline
\end{tabular}


Table 1. Cont.

\begin{tabular}{|c|c|c|c|c|c|}
\hline No. & Date & Speaker & Affiliation & Title & Classification \\
\hline \multirow[t]{5}{*}{7} & 1 December 2018 & Nakagawa S & Tokai U. & $\begin{array}{l}\text { How to utilize the portable DNA/RNA } \\
\text { sequencer MiniON for disaster medical care }\end{array}$ & POCT \\
\hline & & Mori K & SGH & $\begin{array}{l}\text { Kidney disease biomarkers in disaster } \\
\text { infectious diseases }\end{array}$ & Biomarker \\
\hline & & Kaji M & $\mathrm{SCHC}$ & $\begin{array}{l}\text { Measures against infectious diseases in the } \\
\text { event of a disaster }\end{array}$ & DRI \\
\hline & & Hattori T & KIUI & $\begin{array}{c}\text { Disaster measures learned from South } \\
\text { East Asia }\end{array}$ & Resilience \\
\hline & & Ueda T & CMDS & $\begin{array}{l}\text { Earthquake and tsunami countermeasures } \\
\text { in Shizuoka prefecture }\end{array}$ & DRR \\
\hline \multirow[t]{4}{*}{8} & 16 November 2019 & Goka K & NIES & $\begin{array}{l}\text { Fire ants, ticks, mosquitoes-biological risks } \\
\text { caused by environmental disturbances } \\
\text { and globalization }\end{array}$ & DRI \\
\hline & & Kawaguchi T & KHSU & $\begin{array}{l}\text { Infection prevention and control during } \\
\text { natural disaster: lessons learned from the } \\
\text { Kumamoto Earthquake }\end{array}$ & DRI \\
\hline & & Tosaka N & SGH & $\begin{array}{l}\text { Repones of medical institutions in infectious } \\
\text { disease crisis management }\end{array}$ & DRHM \\
\hline & & Ueda $\mathrm{T}$ & CMDS & Shizuoka prefecture disaster prevention drill & DRR \\
\hline \multirow[t]{4}{*}{9} & 20 March 2021 & Miyasaka M & Osaka U. & $\begin{array}{l}\text { What did we learn from a novel } \\
\text { coronavirus infection? }\end{array}$ & COVID-19 \\
\hline & & Takahashi A & KIUI & $\begin{array}{l}\text { Japanese immune strategy and measures } \\
\text { against medical collapse }\end{array}$ & COVID-19 \\
\hline & & Yano K & HMC & $\begin{array}{l}\text { About new coronavirus information } \\
\text { from CDC }\end{array}$ & COVID-19 \\
\hline & & Iwai K & $\mathrm{ShCH}$ & COVID-19 from the medical side & COVID-19 \\
\hline \multirow[t]{5}{*}{10} & 27 November 2021 & Ishii K & IMS & $\begin{array}{l}\text { Disruptive innovation in vaccine } \\
\text { development research advancing } \\
\text { COVID-19 disaster }\end{array}$ & COVID-19 \\
\hline & & Iwatani Y & NMC & $\begin{array}{l}\text { Characteristics and mutations in } \\
\text { SARS-CoV-2 }\end{array}$ & COVID-19 \\
\hline & & Fujimi S & OGMC & $\begin{array}{l}\text { Response of the critical care center in Osaka } \\
\text { during the COVID-19 pandemic }\end{array}$ & COVID-19 \\
\hline & & Ashino $Y$ & $\mathrm{SDCH}$ & $\begin{array}{l}\text { COVID-19 treatment recommendations from } \\
\text { Sendai city hospital }\end{array}$ & COVID-19 \\
\hline & & Terao C & SGH & Cloned cell proliferation and infection & COVID-19 \\
\hline
\end{tabular}

We must strengthen the sustainable use and management of ecosystems and implement integrated environmental and natural resource management approaches that incorporate disaster risk reduction. Through their experience and traditional knowledge, indigenous peoples provide an important contribution to the development and implementation of plans and mechanisms, including early warning and water safety $[4,16]$. Therefore, to increase resilience from disaster-related damage, learning to live in harmony with nature was advocated by Thai indigenous Karen peoples. The hill people can only live with intact forest. An intact forest must have seven layers, which include four aboveground layers. A tree in an intact forest must always follow this pattern: the large tree is at the center, while saplings and bushes- the living quarters of birds and insects-surround this tree. Just below the center and above the bushes and saplings are trees whose branches orchids attach to, drawing nutrients from the trees. At the lower levels are grasses and mushrooms. As for the sub-surface layers, there are roots, tubers, worms, snakes, sweet potatoes, and taros. However, if one element is missing, the system is degraded and cannot survive [17]. Living with nature appears to help recovery from disaster (Figure 2). 


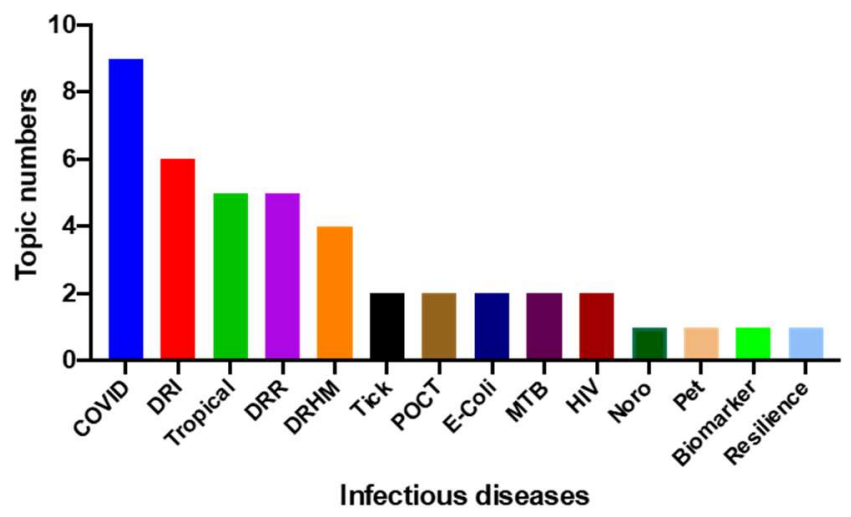

Figure 1. The topic classification of seminar contents. Abbreviation: COVID, COVID-19; DRI, Disaster-related infectious disease; Tropical, Tropical infectious diseases; DRR, Disaster-risk reduction; DRHM, Disaster-risk health management; Tick, Tick-borne diseases; POCT, Point of care test; E. coli, Escherichia coli; MTB, Mycobacterium tuberculosis; HIV, Human immunodeficiency virus; Noro, Norovirus; Pet, Pet-derived infectious diseases.

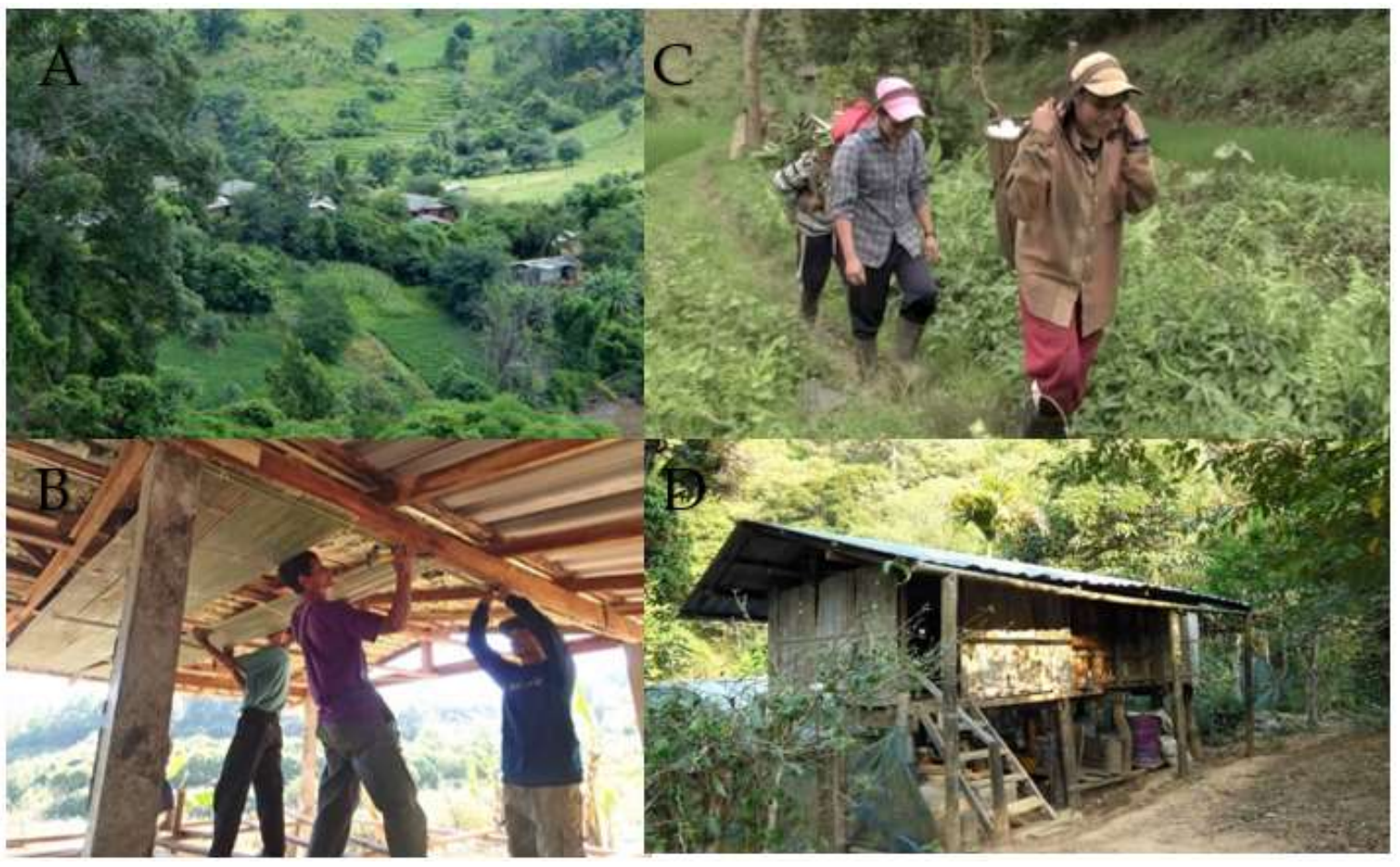

Figure 2. Lives of indigenous people at Ban Huai Hin Lat Nai in Chaing rai. (A) Houses are protected by tropical rainforest. (B) Houses being built by villagers. (C) Self-sufficiency and cultivation while protecting the forest. (D) Stilt food storage. (Photos are courtesy of Mr. Kunio Miyairi and Prof. Tatsuhiko Kawashima, GONGOVA, 2018).

Four lectures on disaster risk health management were also performed to understand the medical system's approach to disasters. In the Kumamoto area of Kyushu, Japan, an Mj 7.3 mainshock occurred on 16 April 2016, close to the epicenter of an Mj 6.5 foreshock that occurred about $28 \mathrm{~h}$ earlier [18]. How the disaster base hospitals worked against these disasters was also presented. Six lectures on disaster-related infectious diseases (DRI) shared knowledge on these diseases, including bacillary dysentery after floods [5] and norovirus outbreaks after Hurricane Katrina despite intensive public health measures [19]. Oysters in the Tohoku area carry norovirus, which causes food poisoning. Oyster contamination correlates with food poisoning and diarrhea outbreaks caused by Escherichia coli in Shizuoka [20]. 
Tetanus occurrence after the Aceh earthquake and tsunami in 2004 [21] and tuberculosis outbreaks after the Haiti earthquake were mentioned in another lecture [7,8]. Understanding the seasonality of tuberculosis (TB) epidemics may help identify potentially modifiable risk factors. Sumi et al. confirmed differences in the seasonality of the prevalence data for sputum smear-positive (SSP) and sputum smear-negative (SSN) pulmonary TB cases in Wuhan [22]. To control SSP pulmonary TB cases, they suggested investigating the periodic structures of SSP and SSN pulmonary TB cases' temporal patterns individually. Attendants often talked about each of these diseases. Twenty pathogens (Table 2) were described in this seminar. For early diagnosis of DRI, biomarkers' roles were presented, including galectin-9 (Gal-9) in dengue fever (DF) [9], malaria [23], and osteopontin (OPN) in leptospirosis [24]. Neutrophil gelatinase-associated lipocalin (Ngal) and other tubular dysfunction markers were also introduced to diagnose acute kidney injury (AKI) [25,26].

Table 2. Pathogens discussed at the seminars.

\begin{tabular}{|c|c|c|}
\hline \multicolumn{3}{|c|}{ Classification (No.) and Pathogens } \\
\hline \multirow[t]{2}{*}{ Virus infection (17) } & RNA (14) & $\begin{array}{l}\text { Human Immunodeficiency Virus (HIV); } \\
\text { Coronavirus type 1, type 2; } \\
\text { Middle east respiratory virus syndrome; } \\
\text { Ebola virus; } \\
\text { Dengue virus; } \\
\text { Zika virus; } \\
\text { Severe fever with thrombocytopenia syndrome } \\
\text { virus; } \\
\text { Rabies; } \\
\text { Lyssavirus; } \\
\text { Influenza virus; } \\
\text { Norovirus; } \\
\text { Hepatitis C virus; } \\
\text { Measles virus; } \\
\text { Rubella virus. }\end{array}$ \\
\hline & DNA (3) & $\begin{array}{l}\text { Human papilloma virus; } \\
\text { Hepatitis B virus; } \\
\text { Varicella zoster virus; } \\
\text { Chickenpox virus. }\end{array}$ \\
\hline Bacteria (8) & $\begin{array}{l}\text { Mycobacterium tuberculosis; } \\
\text { Escherichia coli; } \\
\text { Clostridium tetani; } \\
\text { Legionella; } \\
\text { Leptospira spp.; } \\
\text { Bartonella henselae; } \\
\text { Coxiella burnetii; } \\
\text { Chlamydia psittaci. }\end{array}$ & \\
\hline Fungi (1) & Chytrid fungi & \\
\hline Parasite (2) & $\begin{array}{l}\text { Plasmodium falciparum Malaria; } \\
\text { Trypanosoma cruzi; }\end{array}$ & \\
\hline
\end{tabular}

Table 2 lists the pathogens discussed at the conference. Interestingly, 17 out of 28 (about $60 \%$ ) are viruses, and 14 out of $17(82 \%)$ are RNA viruses. It is worth mentioning that representative zoonotic pathogens, such as Coronavirus, Influenza virus, Ebola virus, Rabies lyssavirus, and Leptospira, were discussed. Therefore, it is necessary to set human and animal life as countermeasure targets for preventing disaster-related infectious diseases. At the same time, it is necessary to further in vivo research on pathogens such as RNA viruses, as described here.

\section{Disaster-Related Infectious Diseases}

\subsection{Leptospirosis}

Leptospirosis is zoonotic, often occurs after floods, and is mainly endemic to subtropical or tropical countries. It has not been reported since 2009 in the Tohoku region (northern Japan). However, four patients with leptospirosis were found in the region between 2012 
and 2014. These cases imply that leptospirosis has reemerged in the region, probably due to global warming [27]. In the Philippines, leptospirosis occurs after floods caused by typhoons or heavy rainfall. The main pathogens consist of numerous serovars $(>250)$. The case fatality rate is $10-20 \%$, and the majority of patients, about $85 \%$, are young males. In addition to rats, its main reservoirs are animals such as wild rodents, herbivores, livestock, and pets, which transmit leptospires through Leptospira-colonized water with urinary excretion in the environment $[28,29]$. Dominant Leptospira serovars with high virulence include L. interrogans serovar Manilae, L. interrogans serovar Losbanos, L. interrogans serovar Ratnapura, and L. borgpetersenii. After a storm surge during the super typhoon Haiyan (Yolanda), pathogenic Leptospira survived in coastal soil in Leyte. Metrological factors showed that leptospirosis occurrence is associated with floods following monsoons in Manila. Besides rainfall, leptospirosis is also associated with relative humidity and temperature in the Philippines. The peak occurrence of leptospirosis preceded DF by only one month, despite occurring 2-3 months later than the peak occurrence of dengue in Thailand [6].

We conducted a biomarker analysis of leptospirosis using two representative matricellular proteins, OPN and Gal-9, in plasma. Both the full-length Gal-9 (FL-Ga19) and OPN (FL-OPN) had increased levels of leptospirosis. Compared to other infectious diseases, pFL-Gal-9 levels showed an inverse correlation with pFL-OPN levels $(r=-0.24, p<0.05)$, but no correlation with other markers. By contrast, pFL-OPN levels correlated significantly with other markers of kidney injury, indicating that FL-OPN levels reflect kidney injury in leptospirosis. N-gal was associated with tubular dysfunction in AKI [25].

\subsection{Tick-Borne Disorders}

Scrub typhus or "Tsutsugamushi disease" was recognized in Japan as a Japanese flood fever with high mortality [30]. A recent study in Laos suggested that O. tsutsugamushi infection is an important cause of central nervous system infections in Laos [31]. Global warming causes changes to all living things on earth. Tick-borne Lyme disease is increasing annually in the United States and Canada [32], and tick-borne encephalitis (TBE), Lyme borreliosis (LB), and emerging borrelial relapsing fever are widespread in Russia [33,34]. The increased number and distribution of ticks, vulnerability to rain, and increased wild animals, which are sources of blood-sucking for ticks, are involved. Tick and tick-borne pathogen surveillance efforts improve our understanding of geographic variation in risk factors for tick-borne diseases, and efforts to build such programs have increased in recent years [35].

\subsection{Mosquito-Borne Disorders}

Disasters change the behaviors of vectors and increase the incidence of vector-borne diseases, including malaria and DF [36]. Unlike the immediate impacts of flooding, malaria epidemics emerge after the acute phase of the crisis has passed. Heavy precipitation is thought to flush established larval habitats; however, malaria vectors rapidly reestablish, and a surge in disease may occur months after the disaster. Chemo-prevention is useful for reducing the excess disease burden associated with a severe flood [37]. It has also been suggested that DF cases in Manila are influenced by monsoon occurrence, contemporaneous with high temperature, high relative humidity, and heavy rainfall. Heavy rainfall precedes the occurrence of DF cases by two months. This timing can be attributed to the life-cycle of mosquitoes and an adequate number of cases for transmission, which is affected by population density [6]. An epidemic from imported DF occurred in Japan in 2014 and 200 cases were diagnosed. According to the analysis of virus strains, it was found that a single strain may have caused Dengue virus (DENV) cases in Tokyo. It should be noted that the plasma levels of Gal-9 are elevated in both DF and malaria. In malaria, Gal-9 levels were higher at day 0 compared with day 7 and day $28(p<0.0001)$. Gal-9 levels were significantly higher in severe malaria (SM) cases than uncomplicated (UM) cases on days 0 and 7 . Therefore, Gal-9 is released during acute malaria and reflects its 
severity in malaria infections [23]. In DENV infection, Gal-9 levels in the critical phase were significantly higher in DENV-infected patients compared with healthy patients or those with non-dengue febrile illness. The highest Gal-9 levels were observed in dengue hemorrhagic fever (DHF) patients. Gal-9 levels significantly declined from peak levels in DF and DHF patients in the recovery phase. Gal-9 levels tracked viral load and reflected the severity of DENV infection [9]. Finally, a dipstick DNA chromatography assay, a single-tag hybridization-printed array strip (STH-PAS), was evaluated for its efficacy in detecting DENV. PCR amplified reverse-transcribed DNA, and the amplified DNA was detected using the STH-PAS system. In clinical studies, the STH-PAS system showed $100 \%$ sensitivity with 88.9 and $86.6 \%$ specificities compared to Taqman RT-PCR and the SD Dengue Duo NS1 test, respectively. The STH-PAS system was found to have a superior sensitivity to the Taqman system [11].

\section{COVID-19 Caused a Disaster}

The COVID-19 outbreak is primarily a human tragedy, affecting countless people. Thus, many countries have undergone lockdowns, restricting their economic agents from mobilizing from one country to another, even nationally, due to the communicable COVID-19. The virus has had a growing impact on the global economy; unfortunately, the global health crisis has become a global economic crisis due to the cancellation of flights, restriction of labor mobility, volatility in stock markets, and so on. For vulnerable families, loss of income due to the outbreak translates to spikes in poverty, missed meals for children, and reduced access to healthcare beyond COVID-19 [38]. It also affects the education of surgeons in the medical community. Residents and young surgeons have shown a substantial decrease in clinical experience, affecting resident education and practice, and variable access to personal protective equipment (PPE). These wasteful efforts have resulted in emotional problems and burnout [39]. Internationally, governments have been enforcing travel bans, quarantine, isolation, and social distancing. Extended periods spent at home have resulted in reduced physical activity, changes in dietary intake with the potential to accelerate sarcopenia, deterioration of muscle mass and function (especially in older populations), as well as increases in body fat [40]. It was also revealed that SARS-CoV-2 has a lower mutation rate than other RNA viruses because it encodes proofreading enzyme genes. Nevertheless, ongoing rapid transmission between humans increases the genetic diversity of SARS-CoV-2 genomes, especially the Spike gene (or the receptor-binding domain, RBD); the latter is advantageous in virus infectivity, immune escape, and tolerance [41]. Interestingly, these glocally occurring viral genetic changes display a convergent evolution of the SARS-CoV-2 genome worldwide [42]. Therefore, worldwide surveillance of the SARS$\mathrm{CoV}-2$ genome is important to understanding future epidemics and may help us control COVID-19. The historical background of mRNA-based vaccine development was also introduced during the seminar [43]. Furthermore, immunogenicity and BNT162b2, a lipid nanoparticle-formulated, nucleoside-modified RNA (modRNA) encoding the SARS-CoV-2 full-length spike, modified by two proline mutations that lock it in the prefusion conformation, were proven to be safe and effective [44]. Identifying risk factors for COVID-19 infection is critical to public health importance. Mosaic chromosomal alteration (mCA), a clonal expansion of leukocytes with somatic chromosomal abnormalities, is associated with an increased risk of many infectious diseases, including severe COVID-19 infection [45]. mCA is strongly associated with males and the elderly; however, the association was significant even after controlling for covariates such as age and sex. The presence of cancer enhanced this association. There was also a trend that the higher the patient's fraction of $\mathrm{mCA}$, the higher the infection rate, suggesting that the expansion of cells with large mutations resulted in abnormal immune dysfunction. This mechanism is interesting; targeting abnormally expanded cells may present a new treatment for many infections, including COVID-19. It would be reasonable to stratify people by the presence or absence of mCA, carefully monitor the infections of those with $\mathrm{mCA}$, and provide appropriate advice according to infection risk inferred from the presence or absence of mCA. SARS-CoV-2 RNA 
in concentrated and purified saliva specimens was detected 37 days after onset, using sugar chain-immobilized gold nanoparticles. It was suggested that early morning saliva specimens are more likely to show positive results than those obtained later in the day [46].

An intravenous administration of the anti-interleukin-6 receptor antibody tocilizumab (TCZ; $400 \mathrm{mg}$ ) effectively treated a patient with COVID-19 pneumonia and a kidney injury. An early administration of TCZ was proposed to prevent pneumonia and kidney injury caused by COVID-19 from progressing to hyperinflammatory syndrome [47]. Plasma levels of FL-Gal9 and FL-OPN and their truncated forms (Tr-Gal9, Ud-OPN, respectively) represent inflammatory biomarkers. For COVID-19 infection, Spearman's correlation analysis showed that Tr-Gal9, Ud-OPN, but not FL-Gal9 and FL-OPN, were significantly associated with laboratory markers for lung function, inflammation, coagulopathy, and kidney function in CP patients. It was proposed that the cleaved forms of OPN and Gal-9 can be used to monitor the severity of pathological inflammation and therapeutic effects of TCZ in CP patients [48].

\section{Discussion}

Three times more natural disasters occurred from 2000 to 2009 than 1980 to 1989. Climate-related events have increased, accounting for nearly $80 \%$ [49]. It is urgent and critical to anticipate, plan for and reduce disaster risk to protect persons, communities, and countries, their livelihoods, health, cultural heritage, socioeconomic assets, and ecosystems effectively, thus strengthening their resilience [4]. We must initiate measures against Nankai Trough Mega Earthquake [3]. In this manuscript, we summarized 10 consecutive seminars on disaster-related infectious diseases. Various topics, including disaster risk reduction, were discussed. Speakers mentioned various pathogens associated with disasters; about $60 \%$ of them (17 out of 28 ) are viruses, and 14 out of 17 (82\%) are RNA viruses. RNA viruses evolve rapidly. The high mutation frequency in RNA virus populations is one source of their ability to rapidly change. A high mutation frequency is a central tenet of the quasi-species theory. Unlike RNA viruses, DNA-based organisms generally have lower mutation frequencies and do not exist near the error threshold [50].

Among the many disaster-related infectious diseases, we proposed that AIDS associated with TB (AIDS/TB) is a disaster because deaths caused by AIDS and tuberculosis (TB) account for $47 \%$ of all deaths in South Africa [13]. The encroachment of HIV into TB endemic areas may expand AIDS/TB. We have been researching novel biomarkers to detect AIDS/TB in patients from India [51] and have continued our study as part of a JICA grass-roots project.

The recent COVID-19 pandemic caused by SARS-CoV2 is a global crisis. Genome sequencing early in the pandemic showed that single nucleotide mutations, multi-base insertions and deletions, recombination, and variation in surface glycans all generate the variability that, guided by natural selection, enables both HIV-1's extraordinary diversity and SARS-CoV-2's slower pace of mutation accumulation. Although SARS-CoV-2's diversity is more limited, recently emergent SARS-CoV-2 variants carry Spike mutations with important phenotypic consequences in antibody resistance and enhanced infectivity [52]. This rate of change is about half that of influenza, and one-quarter of HIV owing to the error-correcting enzyme coronaviruses possess, rare among other RNA viruses. There are probably thousands of viral particles in any given infection, each with unique single-letter mutations; however, few if any of these cause the virus to be more infectious. Omicron's rise may be largely due to its ability to infect people immune to Delta through vaccination or previous infection [53].

At the seminar discussed here, we shared our knowledge about the clinical manifestations of various infectious diseases, pathogens, and progress in diagnostic methods. In addition, the significance of matricellular proteins such as OPN and Gal-9, which were reported as markers of severity for tropical infectious diseases, was reconfirmed in COVID-19 infection. Further examination revealed that protease cleaves these proteins, suggesting that cleaved products exert new pathological functions and become new severity mark- 
ers $[54,55]$. On the other hand, the countermeasures against COVID-19, which caused the disasters worldwide, have introduced a great deal of knowledge about the pathophysiology and infectious mode of disaster-related infectious diseases. Furthermore, measures against infectious diseases are different for each country. Therefore, it is necessary to conduct such disaster-related infection control seminars on an international scale and share knowledge from each country.

Author Contributions: Conceptualization, T.H., S.K., Y.Y. and I.T.; data curation, H.C.-Y.; writing, T.H. and Y.Y.; funding acquisition, T.H. All authors have read and agreed to the published version of the manuscript.

Funding: This work was partially supported by the Japan Society for the Promotion of Science (JSPS) Grants-in-Aid for Scientific Research (KAKENHI), Grant Number 23256004, 26257506, JP17H01690.

Institutional Review Board Statement: Not applicable.

Informed Consent Statement: Not applicable.

Data Availability Statement: Not applicable.

Acknowledgments: We would like to thank all the speakers listed in Table 1. We would also like to thank the staff of SGH for operating the seminar.

Conflicts of Interest: The authors declare no conflict of interest.

\section{Abbreviations}

JBCL Japan Biosciences Co., Ltd.; (Sendai, Miyagi, Japan)

$\mathrm{U}$. University

IRIDeS

SMU

SGH

SSH

NCGM

SCHC

SSK

TBA

NIID

KIUI

CMDS

NIES

KHSU

$\mathrm{ShCH}$

IMS

NMC

International Research Institute of Disaster Science;

(Tohoku University, Sendai, Miyagi, Japan)

Sapporo Medical University; (Sapporo, Hokkaido, Japan)

Shizuoka General Hospital; (Shizuoka, Shizuoka, Japan)

Saiseikai Shizuoka Hospital; (Shizuoka, Shizuoka, Japan)

National Center for Global Health and Medicine;(Tokyo, Japan)

Shizuoka City Health Center; (Shizuoka, Shizuoka, Japan)

Saiseikai Kumamoto Hospital; (Kumamoto, Kumamoto, Japan)

Tohoku Bio-Array Co., Ltd.; (Sendai, Miyagi, Japan)

National Institute for Infectious Disease; (Tokyo, Japan)

Kibi International University; (Takahashi, Okayama, Japan)

Crisis Management Department Shizuoka; (Shizuoka, Shizuoka, Japan)

National Institute for Environmental Studies;(Tsukuba, Ibaragi, Japan)

Kumamoto Health Science University; (Kumamoto, Kumamoto, Japan)

Shizuoka City Hospital; (Shizuoka, Shizuoka, Japan)

OGMC

The Institute of Medical Science;(Tokyo, Japan)

$\mathrm{SDCH}$

E. coli

DRI

DRR

Nagoya Medical Center; (Nagoya, Aichi, Japan)

Tropical

Osaka General Medical Center; (Osaka, Osaka, Japan)

DRHM

MTB

Sendai City Hospital; (Sendai, Miyagi, Japan)

HIV

Esherichia coli

Disaster related infectious diseases

POCT

Disaster risk reduction

Tropical infectious diseases

Disaster risk health management

Mycobacterium tuberculosis

Tick

Human immunodeficiency virus

Point of care test

Pet infection

Tick-borne diseases

COVID-19

Pet-derived infectious diseases

Coronavirus Disease in 2019 


\section{References}

1. Center for Research on the Epidemiology of Disasters, Natural Disaster 2019. Available online: https:/ /landsliderisk.wordpress. com/2020/08/28/cred-report-natural-disasters-2019/ (accessed on 30 December 2021).

2. Hattori, T.; Chagan-Yasutan, H.; Shiratori, B.; Egawa, S.; Izumi, T.; Kubo, T.; Nakajima, C.; Suzuki, Y.; Niki, T.; Alisjahbana, B.; et al. Development of Point-of-Care Testing for Disaster-Related Infectious Diseases. Tohoku J. Exp. Med. 2016, 238, 287-293. [CrossRef]

3. Ministry of Land, Infrastructure, Transport and Tourism. Overview of Nankai Trough Mega Earthquake Operation Plan; MLITT: Tokyo, Japan, 2021.

4. UNDRR. Sendai Framework for Disaster Risk Reduction 2015-2030; UNDRR: Geneva, Switzerland, 2016.

5. Torgerson, P.; Hagan, J.; Costa, F.; Calcagno, J.; Kane, M.; Martinez-Silveira, M.S.; Goris, M.G.A.; Stein, C.; Ko, A.; Abela-Ridder, B. Global Burden of Leptospirosis: Estimated in Terms of Disability Adjusted Life Years. PLoS Negl. Trop. Dis. 2015, 9, e0004122. [CrossRef]

6. Sumi, A.; Telan, E.F.O.; Chagan-Yasutan, H.; Piolo, M.B.; Hattori, T.; Kobayashi, N. Effect of temperature, relative humidity and rainfall on dengue fever and leptospirosis infections in Manila, the Philippines. Epidemiol. Infect. 2017, 145, 78-86. [CrossRef]

7. Furin, J.; Mathew, T. Tuberculosis Control in Acute Disaster Settings: Case Studies from the 2010 Haiti Earthquake. Disaster Med. Public Health Prep. 2013, 7, 129-130. [CrossRef]

8. Koenig, S.P.; Rouzier, V.; Vilbrun, S.C.; Morose, W.; Collins, S.E.; Joseph, P.; Decome, D.; Ocheretina, O.; Galbaud, S.; Hashiguchi, L.; et al. Tuberculosis in the aftermath of the 2010 earthquake in Haiti. Bull. World Health Organ. 2015, 93, 498-502. [CrossRef]

9. Chagan-Yasutan, H.; Ndhlovu, L.; Lacuesta, T.L.; Kubo, T.; Leano, P.S.A.; Niki, T.; Oguma, S.; Morita, K.; Chew, G.M.; Barbour, J.D.; et al. Galectin-9 plasma levels reflect adverse hematological and immunological features in acute dengue virus infection. J. Clin. Virol. 2013, 58, 635-640. [CrossRef]

10. Phetsuksiri, B.; Rudeeaneksin, J.; Srisungngam, S.; Bunchoo, S.; Roienthong, D.; Mukai, T.; Nakajima, C.; Hamada, S.; Suzuki, Y. Applicability of In-House Loop-Mediated Isothermal Amplification for Rapid Identification of Mycobacterium tuberculosis Complex Grown on Solid Media. Jpn. J. Infect. Dis. 2013, 66, 249-251. [CrossRef]

11. Liles, V.R.; Pangilinan, L.-A.S.; Daroy, M.L.G.; Dimamay, M.T.A.; Reyes, R.S.; Bulusan, M.K.; Dimamay, M.P.S.; Luna, P.A.S.; Mercado, A.; Bai, G.; et al. Evaluation of a rapid diagnostic test for detection of dengue infection using a single-tag hybridization chromatographic-printed array strip format. Eur. J. Clin. Microbiol. 2019, 38, 515-521. [CrossRef]

12. Mitsuhashi, S.; Kryukov, K.; Nakagawa, S.; Takeuchi, J.S.; Shiraishi, Y.; Asano, K.; Imanishi, T. A portable system for rapid bacterial composition analysis using a nanopore-based sequencer and laptop computer. Sci. Rep. 2017, 7, 5657. [CrossRef]

13. The 2012 National Antenatal Sentinel HIV E Herpes Simplex Type-2 Prevalence Survey in South Africa; Directorate Epidemiology Cluster, HIMME National Department of Health: Pretoria, South Africa, 2013.

14. Hu, B.; Guo, H.; Zhou, P.; Shi, Z.-L. Characteristics of SARS-CoV-2 and COVID-19. Nat. Rev. Microbiol. 2021, 19, 141-154. [CrossRef]

15. Nations United. Human Development Report 1994; Oxford University Press: Oxford, UK, 1994.

16. Fatehpanah, A.; Jahangiri, K.; Seyedin, S.H.; Kavousi, A.; Malekinezhad, H. Water safety in drought: An indigenous knowledgebased qualitative study. J. Water Health 2020, 18, 692-703. [CrossRef]

17. McKinnon, J. Community culture: Strengthening persistence to empower resistance. In Living at the Edge of Thai Society; Routledge: Oxfordshire, UK, 2003; pp. 64-85.

18. Kato, A.; Nakamura, K.; Hiyama, Y. The 2016 Kumamoto earthquake sequence. Proc. Jpn. Acad. Ser. B 2016, $92,358-371$. [CrossRef]

19. Yee, E.L.; Palacio, H.; Atmar, R.L.; Shah, U.; Kilborn, C.; Faul, M.; Gavagan, T.E.; Feigin, R.D.; Versalovic, J.; Neill, F.H.; et al. Widespread Outbreak of Norovirus Gastroenteritis among Evacuees of Hurricane Katrina Residing in a Large "Megashelter" in Houston, Texas: Lessons Learned for Prevention. Clin. Infect. Dis. 2007, 44, 1032-1039. [CrossRef]

20. Harada, T.; Hiroi, M.; Kawamori, F.; Furusawa, A.; Ohata, K.; Sugiyama, K.; Masuda, T. A food poisoning diarrhea outbreak caused by enteroaggregative Escherichia coli serogroup O126:H27 in Shizuoka, Japan. Jpn. J. Infect. Dis. 2007, 60, $154-155$.

21. Pascapurnama, D.N.; Murakami, A.; Chagan-Yasutan, H.; Hattori, T.; Sasaki, H.; Egawa, S. Prevention of Tetanus Outbreak Following Natural Disaster in Indonesia: Lessons Learned from Previous Disasters. Tohoku J. Exp. Med. 2016, 238, $219-227$. [CrossRef]

22. Luo, T.; Sumi, A.; Zhou, D.; Kobayashi, N.; Mise, K.; Yu, B.; Kong, D.; Wang, J.; Duan, Q. Seasonality of reported tuberculosis cases from 2006 to 2010 in Wuhan, China. Epidemiol. Infect. 2014, 142, 2036-2048. [CrossRef]

23. Dembele, B.P.P.; Chagan-Yasutan, H.; Niki, T.; Ashino, Y.; Tangpukdee, N.; Shinichi, E.; Krudsood, S.; Kano, S.; Hattori, T. Plasma levels of Galectin-9 reflect disease severity in malaria infection. Malar. J. 2016, 15, 408. [CrossRef]

24. Chagan-Yasutan, H.; Hanan, F.; Niki, T.; Bai, G.; Ashino, Y.; Egawa, S.; Telan, E.F.O.; Hattori, T. Plasma Osteopontin Levels is Associated with Biochemical Markers of Kidney Injury in Patients with Leptospirosis. Diagnostics 2020, 10, 439. [CrossRef]

25. Mori, K.; Lee, H.T.; Rapoport, D.; Drexler, I.R.; Foster, K.; Yang, J.; Schmidt-Ott, K.M.; Chen, X.; Li, J.Y.; Weiss, S.; et al. Endocytic delivery of lipocalin-siderophore-iron complex rescues the kidney from ischemia-reperfusion injury. J. Clin. Investig. 2005, 115, 610-621. [CrossRef] 
26. Mori, K.; Mori, N. Diagnosis of AKI: Clinical Assessment, Novel Biomarkers, History, and Perspectives. Acute Kidney Inj. Regen. Med. 2020, 47-58. [CrossRef]

27. Saitoh, H.; Koizumi, N.; Seto, J.; Ajitsu, S.; Fujii, A.; Takasaki, S.; Yamakage, S.; Aoki, S.; Nakayama, K.; Ashino, Y.; et al. Leptospirosis in the Tohoku Region: Re-emerging Infectious Disease. Tohoku J. Exp. Med. 2015, 236, 33-37. [CrossRef] [PubMed]

28. Villanueva, S.Y.A.; Saito, M.; Tsutsumi, Y.; Segawa, T.; Baterna, R.A.; Chakraborty, A.; Asoh, T.; Miyahara, S.; Yanagihara, Y.; Cavinta, L.L.; et al. High virulence in hamsters of four dominant Leptospira serovars isolated from rats in the Philippines. Microbiology 2014, 160, 418-428. [CrossRef] [PubMed]

29. Saito, M.; Miyahara, S.; Villanueva, S.Y.A.M.; Aramaki, N.; Ikejiri, M.; Kobayashi, Y.; Guevarra, J.P.; Masuzawa, T.; Gloriani, N.G.; Yanagihara, Y.; et al. PCR and Culture Identification of Pathogenic Leptospira spp. from Coastal Soil in Leyte, Philippines, after a Storm Surge during Super Typhoon Haiyan (Yolanda). Appl. Environ. Microbiol. 2014, 80, 6926-6932. [CrossRef] [PubMed]

30. Kawamura, R. Studies on tsutsugamushi disease (Japanese flood fever). Med Bull. Coll. Med. Univ. Cincinnati 1926, 4, $217-222$.

31. Dittrich, S.; Rattanavong, S.; Lee, S.J.; Panyanivong, P.; Craig, S.B.; Tulsiani, S.M.; Blacksell, S.; Dance, D.; Dubot-Pérès, A.; Sengduangphachanh, A.; et al. Orientia, rickettsia, and leptospira pathogens as causes of CNS infections in Laos: A prospective study. Lancet Glob. Health 2015, 3, e104-e112. [CrossRef]

32. Marx, G.E.; Spillane, M.; Beck, A.; Stein, Z.; Powell, A.K.; Hinckley, A.F. Emergency Department Visits for Tick Bites-United States, January 2017-December 2019. MMWR. Morb. Mortal. Wkly. Rep. 2021, 70, 612-616. [CrossRef]

33. Krause, P.; Fish, D.; Narasimhan, S.; Barbour, A. Borrelia miyamotoi infection in nature and in humans. Clin. Microbiol. Infect. 2015, 21, 631-639. [CrossRef]

34. Platonov, A.E.; Karan, L.S.; Kolyasnikova, N.M.; Makhneva, N.A.; Toporkova, M.G.; Maleev, V.V.; Fish, D.; Krause, P.J. Humans Infected with Relapsing Fever SpirocheteBorrelia miyamotoi, Russia. Emerg. Infect. Dis. 2011, 17, 1816-1823. [CrossRef]

35. Eisen, R.J.; Paddock, C.D. Tick and Tickborne Pathogen Surveillance as a Public Health Tool in the United States. J. Med. Èntomol. 2021, 58, 1490-1502. [CrossRef]

36. Charnley, G.E.C.; Kelman, I.; Gaythorpe, K.; Murray, K. Understanding the risks for post-disaster infectious disease outbreaks: A systematic review protocol. BMJ Open 2020, 10, e039608. [CrossRef]

37. Boyce, R.M.; Hollingsworth, B.D.; Baguma, E.; Xu, E.; Goel, V.; Brown-Marusiak, A.; Muhindo, R.; Reyes, R.; Ntaro, M.; Siedner, M.J.; et al. Dihydroartemisinin-Piperaquine Chemoprevention and Malaria Incidence After Severe Flooding: Evaluation of a Pragmatic Intervention in Rural Uganda. Clin. Infect. Dis. 2021. [CrossRef] [PubMed]

38. Singh, M.K.; Neog, Y. Contagion effect ofCOVID-19 outbreak: Another recipe for disaster on Indian economy. J. Public Aff. 2020, 2171. [CrossRef] [PubMed]

39. Ellison, E.C.; Shabahang, M.M. COVID-19 Pandemic and the Need for Disaster Planning in Surgical Education. J. Am. Coll. Surg. 2021, 232, 135-137. [CrossRef]

40. Kirwan, R.; McCullough, D.; Butler, T.; De Heredia, F.P.; Davies, I.G.; Stewart, C. Sarcopenia during COVID-19 lockdown restrictions: Long-term health effects of short-term muscle loss. GeroScience 2020, 42, 1547-1578. [CrossRef]

41. Miyasaka, M. COVID-19 and immunity: Quo vadis? Int. Immunol. 2021, 33, 507-513. [CrossRef]

42. Kamikubo, Y.; Takahashi, A. Epidemic trends of SARS-CoV-2 modulated by economic activity, ethnicity, and vaccination. Camb. Open Engag. 2021. Available online: https://researchmap.jp/read0146204/published_papers/31864267 (accessed on 30 December 2021).

43. Sugiyama, T.; Gursel, M.; Takeshita, F.; Coban, C.; Conover, J.; Kaisho, T.; Akira, S.; Klinman, D.M.; Ishii, K.J. CpG RNA: Identification of Novel Single-Stranded RNA That Stimulates Human CD14+CD11c+Monocytes. J. Immunol. 2005, 174, 2273-2279. [CrossRef]

44. Polack, F.P.; Thomas, S.J.; Kitchin, N.; Absalon, J.; Gurtman, A.; Lockhart, S.; Perez, J.L.; Pérez Marc, G.; Moreira, E.D.; Zerbini, C.; et al. Safety and efficacy of the BNT162b2 mRNA COVID-19 vaccine. N. Engl. J. Med. 2020, 383, 2603-2615. [CrossRef]

45. Zekavat, S.M.; Lin, S.-H.; Bick, A.G.; Liu, A.; Paruchuri, K.; Wang, C.; Uddin, M.; Ye, Y.; Yu, Z.; Liu, X.; et al. Hematopoietic mosaic chromosomal alterations increase the risk for diverse types of infection. Nat. Med. 2021, 27, 1012-1024. [CrossRef]

46. Tajima, Y.; Suda, Y.; Yano, K. A case report of SARS-CoV-2 confirmed in saliva specimens up to 37 days after onset: Proposal of saliva specimens for COVID-19 diagnosis and virus monitoring. J. Infect. Chemother. 2020, 26, 1086-1089. [CrossRef]

47. Ashino, Y.; Chagan-Yasutan, H.; Hatta, M.; Shirato, Y.; Kyogoku, Y.; Komuro, H.; Hattori, T. Successful Treatment of a COVID-19 Case with Pneumonia and Renal Injury Using Tocilizumab. Reports 2020, 3, 29. [CrossRef]

48. Bai, G.; Furushima, D.; Niki, T.; Matsuba, T.; Maeda, Y.; Takahashi, A.; Hattori, T.; Ashino, Y. High Levels of the Cleaved Form of Galectin-9 and Osteopontin in the Plasma Are Associated with Inflammatory Markers That Reflect the Severity of COVID-19 Pneumonia. Int. J. Mol. Sci. 2021, 22, 4978. [CrossRef] [PubMed]

49. Leaning, J.; Guha-Sapir, D. Natural Disasters, Armed Conflict, and Public Health. N. Engl. J. Med. 2013, 369, 1836-1842. [CrossRef] [PubMed]

50. Crotty, S.; Cameron, C.E.; Andino, R. RNA virus error catastrophe: Direct molecular test by using ribavirin. Proc. Natl. Acad. Sci. USA 2001, 98, 6895-6900. [CrossRef]

51. Shete, A.; Bichare, S.; Pujari, V.; Virkar, R.; Thakar, M.; Ghate, M.; Patil, S.; Vyakarnam, A.; Gangakhedkar, R.; Bai, G.; et al. Elevated Levels of Galectin-9 but Not Osteopontin in HIV and Tuberculosis Infections Indicate Their Roles in Detecting MTB Infection in HIV Infected Individuals. Front. Microbiol. 2020, 11, 1685. [CrossRef]

52. Fischer, W.; Giorgi, E.E.; Chakraborty, S.; Nguyen, K.; Bhattarcharya, T.; Theiler, J.; Goloboff, P.A.; Yoon, H.; Abfalterer, W.; Foley, B.T.; et al. HIV-1 and SARS-CoV-2: Patterns in the evolution of two pandemic pathogens. Cell Host Microbe 2021, 29, 1093-1110. [CrossRef] 
53. Callaway, E. Beyond Omicron: What's next for COVID's viral evolution. Nature 2021, 600, 204-207. [CrossRef]

54. Iwasaki-Hozumi, H.; Chagan-Yasutan, H.; Ashino, Y.; Hattori, T. Blood Levels of Galectin-9, an Immuno-Regulating Molecule, Reflect the Severity for the Acute and Chronic Infectious Diseases. Biomolecules 2021, 11, 430. [CrossRef]

55. Hattori, T.; Iwasaki-Hozumi, H.; Bai, G.; Chagan-Yasutan, H.; Shete, A.; Telan, E.F.; Takahashi, A.; Ashino, Y.; Matsuba, T. Both Full-Length and Protease-Cleaved Products of Osteopontin Are Elevated in Infectious Diseases. Biomedicine 2021, 9, 1006. [CrossRef] 